\title{
Challenges of Halal Tourism During the Covid- 19 Pandemic in Semarang City
}

\author{
Nur Fauzan Ahmad ${ }^{1 *}$, Muhammad Hermintoyo ${ }^{1}$, and Alvina Maghfiroh ${ }^{1}$ \\ ${ }^{1}$ Faculty of Cultural Sciences, Diponegoro University, Semarang
}

\begin{abstract}
Halal tourism is tourism based on Islamic sharia values. As recommended by the World Tourism Organization (WTO), halal tourism places great emphasis on convenience, such as halal cuisine, worship facilities, and good management. The background of the existence of halal tourism is the number of Muslim tourists which has increased from year to year. Halal tourism aims to facilitate tourists to feel comfortable and still be able to fulfill their religious obligations, especially for Muslim. In its progress, the implementation of halal tourism has experienced ups and downs. Many challenges arise both from internal and external factors. There needs to be a significant improvement and development of this so that it can still exist even in difficult conditions, such as the Covid-19 pandemic which is still ongoing today. This research uses mixed methods, namely quantitative and qualitative method. Collecting data using observation techniques, interviews, and questionnaires. Data analysis used statistical analysis, by processing respondents' answers from questionnaires which distributed by online. The research results are many challenges that arise in the application of halal tourism in the city of Semarang.
\end{abstract}

\section{Introduction}

Nowadays, tourism is starting to be improved and developed, both in terms of concepts, variety, and the latest innovations. The latest innovation that is being defined is halal tourism. For some people, the term halal tourism sounds less familiar. Globally, halal tourism began with the holding of the 1st Organization Islamic Conference (OIC) International Forum on Islamic Tourism in Jakarta, which proclaimed the existence of tourism with an Islamic concept but did not eliminate the element of originality [1].

At the world level, the introduction of halal tourism initially started with a large number of Muslim tourists in many tourist destinations. Based on the 2019 MasterCard-Crescent Rating Travel Market Index (GMTI) Report, the number of Muslim world tourists is predicted to reach 160 million in 2020. This growth will continue to increase to USD 300 billion in 2026 [2].

In Indonesia, halal tourism has been applied to most tourist destinations, although not everyone recognizes and understands the concept. This is related to the position of Indonesia, which ranks the first number as the country with the largest Muslim population in the world. As in the case in the capital city of Central Java, namely the city of Semarang.

* Corresponding author: fazwan.268@gmail.com 
Based on data from the Semarang City Culture and Tourism Office, in 2020, domestic tourists were $3,260,303$ people, while foreign tourists were 6628 people. For more detailed explanation can be seen in the table below:

Table 1. Number of Tourist Visits by Type of Tourist in Semarang City, 2017-2020.

\begin{tabular}{|l|c|c|c|c|}
\hline \multicolumn{1}{|c|}{ Type of Traveler } & $\mathbf{2 0 1 7}$ & $\mathbf{2 0 1 8}$ & $\mathbf{2 0 1 9}$ & $\mathbf{2 0 2 0}$ \\
\hline Domestic Tourist & $4,927,960$ & $5,703,282$ & $7,223,529$ & $3,260,303$ \\
\hline Foreign Tourist & 59,120 & 66.105 & 82.030 & 6.628 \\
\hline Total & $\mathbf{4 , 9 8 7 , 0 8 0}$ & $\mathbf{5 , 7 6 9 , 3 8 7}$ & $\mathbf{7 , 3 0 5 , 5 5 9}$ & $\mathbf{3 , 2 6 6 , 9 3 1}$ \\
\hline
\end{tabular}

Source: Semarang City Culture and Tourism Office [3].

Domestic tourists are natives of Indonesia whom the majority are Muslims. As reported from www.Indonesia.go.id [4], the Muslim population in Indonesia reaches $87.2 \%$. Based on data from the Department of Population and Civil Registration of Semarang City, the Muslim population of Semarang City is $1,470,442$ people. This number is very large when compared to 116,744 Protestants, 86,166 Catholics, 1,236 Hindus, 10,894 Buddhists, and 427 adherents of other religions [5]. Thus, it is clear that the existence of the Muslim community fulfils almost all sectors of life, especially the tourism sector. This condition is a special concern for stakeholders in the tourism sector to develop halal tourism.

From the table above, three years in a row, 2017 until 2019, the number of tourists has increased. However, in 2020 it experienced a drastic decline. This is due to the Covid-19 pandemic, which has attacked most of the world's regions, especially the city of Semarang and its surroundings.

From mid-2020 until now, Indonesia is still worried about the Covid-19 pandemic. That situation changes almost the entire order of life. Skale et al. (in Utami \& Kafabihi, 2021) argue that the tourism sector is the sector most affected by this pandemic [6]. No one can predict when this pandemic will end. Therefore, the Covid-19 pandemic, which is still ongoing today, is a special challenge in the development of halal tourism. The number of tourists has decreased dramatically when compared to before the pandemic. Tourism managers and workers in the tourism sector have complained about the impact of the pandemic. Likewise, with the government, the source of state revenue is slowly receding so that the Gross Domestic Product (GDP) is low.

The tourism sector plays an important role in the world economy because it is considered as one of the factors to job growth and economic growth in any country [7]. Destiana and Retno said that tourism had become one of the main players in international trade and major foreign exchange earnings in many developing countries [8]. The existence of the concept of halal tourism along with the increase in the number of Muslim tourists becomes a potential opportunity and challenge in increasing and developing halal tourism in Indonesia, especially the city of Semarang.

According to the Big Indonesian Dictionary, challenges are things or objects that inspire determination to improve the ability to solve problems. Besides external factors such as the pandemic and tourism enthusiasts, challenges can also come from internal factors of tourism such as the government and tourism managers.

Therefore, this paper aims to analyze the challenges of halal tourism in Semarang City in the ongoing Covid-19 pandemic situation.

\section{Method}

This study uses a combined method, namely quantitative and qualitative descriptive. They were collecting data using observation techniques, interviews and questionnaires. Researchers surveyed the field and conducted direct interviews with randomly selected 
tourists. The tourist destinations that the researchers visited were Sam Poo Kong Temple, Kampung Laut, Lawang Sewu, and Kota Lama. Furthermore, the researchers used a questionnaire with open and closed questions, which were distributed online. Furthermore, the data were analyzed using statistical analysis methods, namely by using the percentage model. The data analysis utilizes Microsoft Excel by comparing and connecting between variables [9]. The data presentation technique uses a combined method, namely formal and informal. The formal method is the presentation in the form of statistics, for example, numbers and tables. While the informal method is a presentation using words so that it is detailed and easy to understand.

\section{Results}

The city of Semarang, as one of the icons in Central Java Province, saves a variety of wonderful tourist destinations. I am starting from natural tourism, artificial tourism, culinary tourism to historical tourism. The implementation of halal tourism in the city of Semarang does not run perfectly, of course, have been a challenge and obstacle.

Based on the questionnaire data, most people have heard the term and know well the concept of halal tourism. People who are often travelling and tour managers admit that they do not want to be unfamiliar with the term halal tourism. The data shows that from 104 respondents, $68.3 \%$ are familiar with the term halal tourism, while $31.7 \%$ have never heard of it. Although they have heard of the term halal tourism, not enough people know the essence of halal tourism. It was noted that $56.7 \%$ had understood the concept of halal tourism, and the leftover did not know.

The definition of halal tourism is a whole of additional amenity services, attractions, and accessibility that are intended and provided to fulfil the experiences, needs and desires of Muslim tourists. In the short term, halal tourism is tourism as usual by applying Islamic concepts, such as adding worship facilities, halal food, and other facilities and access for the needs of Muslim tourists. Lack of knowledge in the community about halal tourism is evidenced by the perception that halal tourism is the same as religious tourism, as $25 \%$ say so. In essence, halal tourism generally occurs and comprehensively to anyone, whether ethnicity, race, religion, circle, profession, and so on, without exception. Thus, halal tourism is not only intended for Muslims because religious tourism and halal tourism are different categories. The respondent community as much as $77.9 \%$ agree that halal tourism occurs to all elements of society without certain boundaries.

After the society got a brief of halal tourism, 97.1\% supported halal tourism, while $2.9 \%$ did not agree. One of the respondents who disagreed argued that there was no need for additional facilities. This number is almost the same as the number of respondents who do not agree if the city of Semarang become a halal tourist destination. There are $3.8 \%$ of respondents who disagree because not all tourist destinations can become halal tourism, like the toilet facilities in Lawang Sewu, which are not separated between men and women in order to preserve the heritage of ancient times. This is closely related to the rules and policies of the ancestors.

Different from respondents' answers regarding the separation of male and female toilets, many respondents admitted to disagreeing about the separation of swimming pools between men and women. As many as $84.6 \%$ chose to be separated, while the leftovers chose to be one. Respondents who disagree argue that not all swimming pools have large and sufficient land to make a separate swimming pool. However, if there are no material problems, a swimming pool separation can be applied. Meanwhile, respondents who agreed argue that the policy was in order to maintain the privilege of Muslim tourists to realizing comfort.

In the Covid-19 pandemic situation, the challenges of halal tourism are increasing. The government must make rules that must be obeyed by all levels of society. The community 
must obey the rules assigned by the government, especially tourism managers and visitors. The application of health protocols with the 5M Movement (Keeping Distance, Washing Hands, Wearing Masks, Avoiding Crowds, and Reducing Mobility) should go on and on and always intensify. In connection with the increase in Covid-19 cases in the city of Semarang and its surroundings, as many as $47.1 \%$ of the society disagree if tourist destinations are opened while the pandemic is still ongoing. This number has increased when the community is asked for opinions about the implementation of health care programs in tourist destinations in Semarang City. It had been noted 69 2\% said that the implementation of the health protocols had not been implemented properly and massively. So it's not surprising that almost some people disagree if tourist destinations are opened during a pandemic.

Information related to tourist destinations in Semarang City obtained by tourists comes from social media is on the highest percentage of $59.6 \%$. This number beats browsing on the internet, conventional mass media, friend's recommendations, and travel agencies. Thus, communication and promotion on social media are felt to be more efficient in disseminating information about tourist destinations. As many as $51.9 \%$ of people choose Semarang city because it is rich in historical places, delicious culinary, good for taking pictures, and so on. The lowest percentage is in the choice of watching traditional arts, which is $7.7 \%$. This is a challenge so that the city of Semarang activates traditional arts.

Most of the people, as much as $78.8 \%$, gave their opinions that the main effort to support Semarang City to become a halal tourist destination is the provision of worship facilities. Then, as many as $54.8 \%$ want the availability of culinary in every tourist destination, and $49 \%$ of the people want comfortable urinal facilities.

\section{Conclusion}

The city of Semarang, as one of the icons in Central Java Province, has a variety of tourist destinations. Which has become a favourite destination for domestic and foreign tourists to seek entertainment, unwind, and others. The implementation of halal tourism in the city of Semarang is still not running perfectly. Some of the challenges that arise along with the improvement and development of halal tourism are as follows:

1. The level of societies knowledge about halal tourism is still low,

2. Almost all people support halal tourism, although there are still a few the respondents who do not support it,

3. A few of the respondents does not support the existence of a separate swimming pool between men and women;

4. Almost some of the respondents did not agree if tourist destinations were opened during the pandemic because the implementation of health protocols had not been carried out massively; and

5. People access information related to tourist destinations mostly through social media.

Halal has become part of the lifestyle of humans, especially Muslims, in carrying out various activities. Nowadays, halal has a broad meaning and has developed over time. The innovation of the halal concept is applied in the tourism sector which namely halal tourism. Many challenges arise both from internal and external factors. From some of the challenges mentioned before, suggestions and recommendations that can be given are the socialization of halal tourism to the overall society through various supporting media, such as television, internet, social media, and print media. When people already know the concept of halal tourism and feel comfortable, then people will agree and support the implementation of halal tourism. 
In relation to the Covid-19 pandemic, it would be nice to limit visitors in all tourist destinations, apply strict health protocols, close on certain days, and enforce other supporting regulations. Tourist destinations remain open by paying attention to government advice. It is undeniable that human instincts definitely need entertainment from a daily routine that is sometimes boring. Thus, people can still travel safely and comfortably.

\section{References}

1. Indonesian Ministry of Tourism 2018, Design of the West Nusa Tenggara Halal Tourism Action Plan Strategy, 4 (2018)

2. Deputy for Industrial and Institutional Development of the Ministry of Tourism, Guidelines for the Implementation of Halal Tourism. Ministry of Tourism Jakarta, 1 (2019)

3. Interview with Semarang City Culture and Tourism Office (May, 2021)

4. Portal Informasi Indonesia (2021) Retrieved from: www.indonesia.go.id

5. Interview with the Semarang City Population and Civil Registration Office (May, 2021)

6. Utami, B. S. Ayu, A. Kafabihi, Indonesia's Tourism Sector in the Midst of the Covid 19 Pandemic, Journal of Economic Dynamics and Development, 4(1), 383-389 (2021)

7. Satriana, E. Dewi, H. D. Faridah, Halal Tourism: Development, Chance, and Challenge, Journal of Halal Products and Research, 1(2), 32-43(2018)

8. Destiana, Riska, R. S. Astuti, Halal Tourism Development in Indonesia, in Conference on Public Administration and Society, 1(1), 331-353 (2019)

9. J. R. Raco76, Qualitative Research Methods: Types, Characteristics, and Advantages, PT Grasindo Jakarta (2010)

10. Deputy for Industrial and Institutional Development of the Ministry of Tourism, Guidelines for the Implementation of Halal Tourism, Ministry of Tourism Jakarta, 3 (2019) 